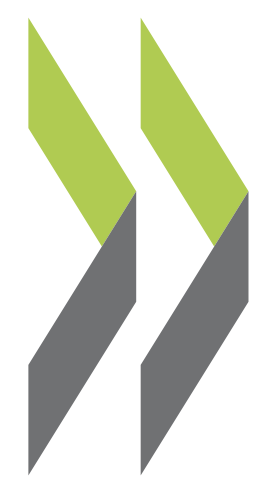

OECD Working Papers on Insurance and Private Pensions No. 34

\title{
Evaluating the Design of Private Pension Plans: Costs and Benefits of Risk- Sharing
}

Hans J. Blommestein, Pascal Janssen, Niels Kortleve, Juan Yermo 


\section{EVALUATING THE DESIGN OF PRIVATE PENSION PLANS COSTS AND BENEFITS OF RISK-SHARING}

Hans Blommestein, Pascal Janssen, Niels Kortleve and Juan Yermo

March 2009

\section{OECDWORKING PAPER ON INSURANCE AND PRIVATE PENSIONS}

No. 34

Financial Affairs Division, Directorate for Financial and Enterprise Affairs

Organisation for Economic Co-operation and Development

2 Rue André Pascal, Paris 75116, France

www.oecd.org/daf/fin/wp 


\section{ABSTRACT/RÉSUMÉ \\ Evaluating the Design of Private Pension Plans: Costs and Benefits of Risk-Sharing}

The principal purpose of this paper is to analyse the trade-off between the uncertainty in contributions on the one hand and benefits on the other that is embedded in different pension arrangements. The paper employs the funding ratio (ratio of assets to liabilities) and the replacement rate (ratio of benefits to salaries) as key criteria for evaluating the risk sharing characteristics of a private pension plan from the perspective of the plan member. The stochastic simulations performed show that hybrid plans (those in between traditional DB and individual DC) appear to be more efficient and sustainable forms of risk sharing than either of the other two. Of the three main hybrid plans analysed, conditional indexation plans appear to have the greatest potential as sustainable forms of risk sharing.

JEL codes: $\mathrm{G} 23, \mathrm{~J} 32$

Key words: defined benefit, defined contribution, funding, hybrid plans, pension benefits, pension funds, risk sharing.

$$
* * * * *
$$

\section{Évaluer la conception des plans de pension privés : coûts et avantages du point de vue du partage des risques}

Le principal objectif de ce document est d'analyser l'arbitrage entre le degré de certitude (d'incertitude) des cotisations, d'une part, et des prestations, d'autre part, inscrit dans les différents systèmes de pension. Le coefficient de capitalisation (rapport des actifs aux engagements) et le taux de remplacement (rapport entre les prestations et le salaire) sont les critères clés considérés pour évaluer les caractéristiques en termes de partage des risques des plans de pension privés du point de vue de l'adhérent à un plan. Les simulations stochastiques réalisées montrent que les plans hybrides (plans qui se situent entre les traditionnels plans à prestations définies et les plans à cotisations définies individuels) semblent être une forme de partage des risques plus efficiente et plus viable que les deux autres. Parmi les trois grands types de plans hybrides analysés, les plans à indexation conditionnelle semblent les plus aptes à assurer un partage des risques de façon pérenne.

Codes JEL : G23, J32

Mots clés : prestations définies, cotisations définies, capitalisation, plans hybrides, prestations de pension, fonds de pension, partage des risques.

\section{Copyright OECD, 2009}

Applications for permission to reproduce or translate all, or part of, this material should be made to: Head of Publications Service, OECD, 2 rue André-Pascal, 75775 Paris Cédex 16, France. 


\title{
EVALUATING THE DESIGN OF PRIVATE PENSION SCHEMES: COSTS AND BENEFITS OF RISK-SHARING
}

\author{
By Hans Blommestein, Pascal Janssen, Niels Kortleve and Juan Yermo ${ }^{1}$
}

\section{Introduction}

The growth of private pensions and their expanding role in retirement income systems calls for a better understanding and management of the risks that they are exposed to. Investment risk features most prominently amongst them, as evidenced by the average decline of 20 percent in OECD private pension assets between January and October 2008 (OECD 2009).

From the perspective of the plan member, private pensions are a form of long-term savings, where contributions today are invested in order to pay for benefits tomorrow. Plan members generally prefer guaranteed benefits, as in a defined benefit (DB) plan, but trade-offs such as the cost of volatility in contributions, need to be taken into account. ${ }^{2}$ Increasingly, however, employers are turning to (collective) defined contribution (DC) plans where contribution rates are fixed but retirement income risks are borne entirely by employees.

The principal purpose of this paper is to analyse the trade-off between the (un)certainty in contributions on the one hand and benefits on the other that is embedded in different pension arrangements. The paper employs the funding ratio (ratio of assets to liabilities) and the replacement rate (ratio of benefits to salaries) as key criteria for evaluating the risk sharing characteristics of a private pension plan or scheme from the perspective of the plan member. The focus is on risk sharing within the various schemes, irrespective of whether it is the employer, employees, or a combination of both that pays contributions.

The main risks to a pension contract are investment risk (and specifically the mismatch between assets and liabilities), inflation risk, biometric risks (of which the most important in a pension plan is longevity risk) and bankruptcy/insolvency risks. The focus in this study is on investment risk and inflation risk, although longevity risk is introduced to study the limits of intergenerational risk sharing via markets.

Higher benefit certainty as a pensioner inevitably leads to greater volatility over contributions as a worker. In other words, the more benefits are protected against investment and inflation risk, the greater will be the need to steer the funding ratio via changes in contribution rates that ultimately affect current workers' incomes. We analyse this basic trade-off across a range of design schemes, ranging from arrangements where risks are completely or partially pooled (DB and hybrid systems) to an arrangement

\footnotetext{
${ }^{1}$ This Working Paper was prepared by Hans Blommestein of the OECD, Pascal Janssen of PGGM, Niels Kortleve of PGGM and Juan Yermo of the OECD. The views expressed herein are those of the authors and do not necessarily reflect those of the IOPS or its members. The authors are solely responsible for any errors.

Contact information: Organisation for Economic Co-operation and Development, 2, rue André Pascal, Paris, F75775, France. E-mail: juan.yermo@ oecd.org.

${ }^{2}$ This preference for DB plans usually abstracts from possible downsides such as lack of portability and the possible absence of an acceptable protection against insolvency of the plan sponsor that guarantees the benefits. In addition, McCarthy (2003) has argued that for younger workers, with large human to financial capital ratios, final pay DB plans may not be optimal.
} 
without pooling (individual DC). All pension arrangements assume that there is a single asset allocation for all members. An extension of this research would allow differentiation of investment policy between age cohorts, offering pensioners the results of a safer investment portfolio.

The stochastic simulations performed show that hybrid plans (those in between traditional DB and individual DC) appear to be more efficient and sustainable forms of risk sharing than either of the other two. Of the three main hybrid plans analysed, conditional indexation plans appear to have the greatest potential as sustainable forms of risk sharing.

Section II provides an introduction to risk sharing in occupational pension arrangements. Section III provides an example of the limitations of risk sharing via the market, highlighting the value of occupational pensions. Section IV evaluates the outcomes of funding ratios and replacement rates for different types of pension plans. The last section concludes.

\section{Two main perspectives on risk sharing in pension arrangements}

The main value of collective or occupational pension plans lies in their potentially low costs of administration and their ability to incorporate different kinds of risk sharing that are not readily available in the market or that are only accessible at a high cost. Risk sharing can be analysed from two different perspectives. First, risks are shared between employees and pensioners on the one hand and the sponsoring employers, on the other. This kind of risk sharing was the subject of a recent OECD study. ${ }^{3}$ Analysing this form of risk sharing requires a discussion of the overall wage setting framework, as pension contributions are normally negotiated as part of the pay bargain process. In theory, the balance between employer and employee contributions is neutral (or irrelevant) because both are part of the total remuneration, so higher employer contributions eventually mean lower salaries (or other benefits).

The second perspective on risk sharing is to focus on the benefits and costs of risk sharing embedded in the various types of pension plans from the angle of members and beneficiaries (pensioners) by assessing how (successfully) the different risks are pooled within the various schemes. From this perspective volatility of contributions constitute a risk for current workers, irrespective of who pays for them. By focusing on within-scheme risk sharing, this paper will evaluate the trade-off between contribution risk (by focusing on the funding ratio) and benefit risk (by using the replacement rate) for the average or representative plan member and pensioner. The analysis could be developed further to calculate the distribution of the net economic value of different forms of plan design across employees of different ages and pensioners as well as its evolution over time across different cohorts. This extension will be analysed in a separate study.

\section{II.a Risk sharing vs. redistribution}

In addition to offering risk-sharing features, occupational pension plans can also involve one-sided or non-reciprocal redistributions between different kinds of workers. For example, the uniform contribution rate that employees of all ages pay in occupational plans of some countries like the Netherlands means that for a given benefit level young workers 'overpay' to acquire the pension rights while older workers 'underpay'. This wealth transfer is partly offset by the lower life expectancies of the old relative to the young at the same age, but given past rates of life expectancy improvements, the net wealth transfer is likely to favour the old. This kind of 'solidarity' between the young and the old was the topic of debates in the Netherlands (see, e.g., Boeijen et al. 2007 and Aarssen and Kuipers, 2007). It has been argued that this transfer may be pushing the young away from defined benefit arrangements in the direction of arrangements emphasising individual features (Boeijen et al. 2007).

\footnotetext{
${ }^{3}$ See Pugh and Yermo (2008).
} 
Interestingly, such concerns seem not to have been voiced in other countries, probably because the share of employee contributions is much lower or nil. ${ }^{4}$ Unlike employee contributions - which indeed in most countries tend to be a fixed percentage of wages - employer contributions to defined benefit pension plans tend follow actuarial cost methods involving increasing contributions as a percentage of salary with the age of the worker. This is the case, for example, of the projected unit credit method, which is nowadays the most popular actuarial cost method and has also been adopted by the organisation in charge of international accounting standards. ${ }^{5}$

More generally, the following types of intended or unintended redistributions arise in occupational pension plans of the defined benefit type that have employee contributions and accrual rates that do not vary with age:

- $\quad$ From the young to the old;

- From those who join the plan early in their lives to those who join it late;

- From those who leave the plan early to those who leave it later;

- From those who have flat earnings profiles to those with steeper earnings profiles towards the end of their career.

Other types of redistributions in defined benefit type that can emerge even if employee contribution rates and accrual rates vary with age are the following:

- When deferred benefits are not revalued like accrued benefits, early leavers lose out at the expense of those who stay in the plan;

- In final pay plans, workers with steeper earnings profiles profit at the expense of workers with flatter profiles;

- Partnered members profit at the expense of single members as their partners obtain survivor's pensions;

- Women on average get more value from equal contributions than men because of their longer average life expectancy. ${ }^{6}$

\section{II.b Key characteristics of risk sharing in different pension arrangements}

Occupational pension arrangements can offer different forms of risk sharing. This section describes briefly the key characteristics of six main types of risk sharing arrangements observed in practice. The first four of these will be evaluated in Section IV.

\footnotetext{
${ }^{4}$ But implicitly employees are paying, because with total remuneration fixed, higher employer contributions imply lower (other) employee benefits.

${ }^{5}$ One criticism of this method is that it incorporates wage increases in benefits (liabilities), while offsetting future contributions on the asset side of the balance sheet are not included. This leads to an inconsistency in valuation methods between assets and liabilities.

${ }^{6}$ There seems also to be a substantial redistribution from lower social (income) classes to higher income classes and from immigrants to autochthonous (see for example CPB study, http://www.cpb.nl/nl/pub/cpbreeksen/discussie/81/disc81.pdf).
} 


\section{(i) Traditional (final pay and career average) DB plans}

In these plans, a formula links benefits to wages and the length of the service period. The replacement rate is fixed as a percentage of the worker's final or career average wage. To the extent that benefits are paid as inflation-indexed annuities, pensioners face no benefit risk. These types of plans therefore shift all risks related to benefit provision to the sponsoring employer, and hence to current and future workers.

\section{(ii) DB plans with conditional indexation}

In these pension arrangements, benefits are calculated as in traditional DB plans except that indexation of pensions in payments and in some cases accrued benefits is conditional on the plan's funded status. The higher is the funding ratio the greater the extent of indexation.

\section{(iii) Cash balance plans}

Under a cash balance plan benefits are calculated on the basis of individual accounts that are credited with a fixed investment return until retirement. At retirement, benefits may be paid as lump-sums or annuities. Cash balance plans is a type of risk-sharing pension arrangement that is free of all the redistributions mentioned earlier. It only protects against investment risk, but not longevity risk before retirement. It may also fail to protect against inflation risk if the investment return guarantee is set at too low a level (or a nominal level only).

\section{(iv) Collective DC plans}

In a collective DC plan, contribution rates are fixed. Benefits are calculated as in traditional DB one but both the extent of indexation and nominal benefits are linked to the plan's funded status. Nominal accrued benefits and even nominal pensions in payment can be cut if the funding ratio falls below a certain level. Pensioners therefore face greater benefit risks than under the previous pension arrangements.

\section{(v) Nursery plans}

Benefits are calculated on a pure (individual) DC basis up to a certain age and DB thereafter. The plan effectively treats early leavers (those who leave their employer before retirement) differently from long-tenure employees. The latter are covered by a traditional DB plan, while the former are fully exposed to benefit risk. Nursery plans, therefore, do not involve a different form of risk sharing to the ones just described.

\section{(vi) Floor or underpin plans}

Benefits are the higher of the outcomes of a DC and a DB formula. For example, the plan may guarantee a minimum rate of return but pay the actual, market rate of return if this is higher. Alternatively, the plan may guarantee minimum benefits and pay higher ones based on a DC formula if these are higher. Such pension deals have many similarities with both conditional indexation and collective DC plans, but do not allow for any steering with the funding ratio. Under such plans, there is no surplus or excess funding, as the actual market return must always credited to benefits if it is higher than the guaranteed level. 


\section{The limits of intergenerational risk sharing via the market}

Before evaluating risk sharing through occupational pension plans one may wonder whether such contracts can always be successfully replicated by the market, specifically when intergenerational risks are involved. Two general approaches or solutions to intergenerational risk sharing can in principle be distinguished. The first approach is based on the principle that pension funds collectively bear intergenerational risks. More precisely, pension funds collectively organise risk sharing by redistributing the risks between various stakeholders including future generations. This implies that these risks are in the end borne by these stakeholders (pension funds act only an (organising) agent and not as a principal; they do not own funds or reserves like insurers do). Given the large population of (future) stakeholders, the price of intergenerational risk sharing is lower when organised via pension funds. The first solution implies that pension funds make markets more complete, meaning that pension funds improve social welfare (assuming that efficient market-based hedging opportunities are not available; see below and annex 1).

The second approach is based on hedging solutions via financial markets (e.g. they buy hedges in the market or they reinsure these risks). The remainder of this section discusses the limits of intergenerational risk-sharing via the market. To illustrate the issues and policy decisions at stake, we will refer to longevity risk as a clear case of an intergenerational risk that poses a great challenge for pension funds to incorporate in pension arrangements.

Idiosyncratic or micro longevity risk (survival risk) can in principle be tackled in an efficient risk sharing fashion via annuities markets. ${ }^{7}$ Unfortunately, private annuity markets are affected by adverse selection. Government action (in the form of e.g. mandatory participation rules) can in principle address this type of market failure.

Aggregate or macro longevity risk affects current cohorts in roughly the same way. Positive correlations across individuals mean that private market solutions cannot be used to share this risk efficiently. ${ }^{8}$ Common tools to minimise exposure to this macro risk (diversification across cohorts, international diversification via cross-border investments, risk sharing with annuitants, or hedging of insurance companies by selling both annuities and life-insurance) cannot completely eliminate it.

Financial markets (including insurance) work efficiently for sharing short-term risks between cohorts (with largely overlapping lifetimes) but not, for example, for the long-term life risks of older cohorts that are largely known when the younger cohorts arrive. Ex ante efficient intergenerational risk sharing via private markets is therefore not possible as future generations cannot be included. ${ }^{9}$ The government, on the other hand, can use fiscal policy (taxes, social insurance, transfers and public debt) as a vehicle to spread risk across generations, thereby (in theory) improving social welfare. To put it differently,

\footnotetext{
${ }^{7}$ For the first pillar this is not necessary, because risk sharing is already incorporated (since first pillar pensions are paid out as annuities), although the government (society) still bears macro longevity risk (see below).

${ }^{8}$ Bohn (2005).

${ }^{9}$ However, even if future generations could be included, potential conflicts cannot be ruled out. For example, let us assume that we can arrange an ex ante fair pension arrangement for all generations, including future ones at $\mathrm{t}=\mathrm{T}$. But by the time that future generations actually join the pension fund at $\mathrm{t}=\mathrm{T}+1$ that 'fair pension deal' (which by the passage of time has become partly ex post) can have either a positive or a negative value for that pension fund-joining generation. If that ex post negative value is considered too large, future generations may opt-out when they are joining the fund at $\mathrm{t}=\mathrm{T}+1$ [even though it was considered ex ante (at $\mathrm{t}=\mathrm{T}$ ) a fair pension deal]. This implies that the expected ex post redistributions should not be 'too large' from the perspective of future generations, because the larger their size, the larger the probability that future generations will opt-out.
} 
governments have in principle the ability to make markets more complete by providing longevity insurance backed by future generations. ${ }^{10}$ This conclusion can be generalised by introducing a social security system in an overlapping-generation economy so as to achieve an optimal intergenerational risk sharing arrangement. ${ }^{11}$

However, government interventions need to take the following considerations into account. ${ }^{12}$ First, government policy need to include important general equilibrium effects of aggregate longevity risks. A (permanent) macro longevity shock not only increases systematically life spans, but has also macroeconomic effects via changes in factor prices and the capital-labour ratio. ${ }^{13}$ It is therefore possible that a longevity shock will increase the (future) supply of labour and decrease (future) wages. ${ }^{14}$

A second consideration is that future ("new") generations are subject to the same longevity shock as the current ("old") generation. But the key difference in terms of impact is that the new generation can use their entire life-span to adjust labour supply, consumption and savings to a jump in longevity, while this is not the case for the old generation. ${ }^{15}$ This perspective creates the possibility of creating welfare gains by sharing some of the financial risks of longevity shocks for the old generation with future generations. And only the government has the power to enforce inter-generational contracts. ${ }^{16}$

A third consideration is that although governments have in principle the tools to spread efficiently risk across generations, this may not occur in practice. Optimal inter-generational risk-sharing may be distorted by $\operatorname{taxes}^{17}$ and social security arrangements. ${ }^{18}$ This means that the optimal degree of intergenerational risk-sharing has not been moved onto the right generation. Governments are already heavily involved in inter-generational risk-sharing via public pensions and other social security arrangements. ${ }^{19}$ It is difficult to demonstrate but the distorting influence of "politics" makes it unlikely that this is the

\footnotetext{
${ }^{10}$ Brown and Orszag (2006), ibid.

${ }^{11}$ See Ball and Mankiw (2007).

${ }^{12}$ Bohn (2005), ibid.

${ }^{13}$ The capital-labour ratio will not be directly affected when retirement ages are fixed. If the retirement age is fixed, a higher life expectancy does not immediately have a direct impact on the labour market. However, financial pressures (including budgetary ones) and the (expected) influence of a permanent macro longevity shock on both financial market prices and output during the retirement stage, may lead to changes in the retirement age. There will also be a direct impact on consumption (savings) and prices. There is also another secondary impact. With a fixed retirement age and an increasing life span, pension benefits will become lower or pension contributions will become more expansive (if we keep pension payments on the same level). The latter implies higher contributions, possibly affecting the price of labour.
}

${ }^{14}$ Brown and Orszag (2006), ibid, note that via these general equilibrium effects future generations would already share (partially) in longevity risk.

${ }^{15}$ Brown and Orszag (2006), ibid.

${ }^{16}$ Naturally, (future) politicians can always break these contracts. Pension reform is to a large degree synonymous with breaking inter-generational contracts. But, hopefully, these reforms engineer a move away from the existing non-optimal degree of inter-generational risk-sharing.

${ }^{17}$ Bohn (2005), ibid

${ }^{18}$ Brown and Orszag (2006), ibid.

${ }^{19}$ See Ball and Mankiw (2007), ibid, for the use of an overlapping-generations model to show how the government influences the allocation of risk among generations through the social security system. 
optimal amount of risk-sharing. For the same reason it is likely that to-days' inter-generational arrangements favour the current generation (of voters) at the expense of future generations. ${ }^{20}$

\section{Evaluation of outcomes under different pension plans}

In order to evaluate the attractiveness of different pension plans we focus on two key performance variables: the funding ratio and the replacement rate. The funding ratio (the ratio of pension plan assets to liabilities) is an indicator of the solvency of the pension plan, used by both regulators and investors. Ratios below $100 \%$ indicate a situation of underfunding, requiring an elimination of the deficit via additional contributions, lower benefits, or both. Funding ratios above $100 \%$, on the other hand, indicate that the plan has excess assets which requires a strategy to allocate that excess over time. Beyond a certain level of excess funding, the pension plan may reduce its contributions, increase its benefits, or take both measures. Variability in the funding ratio reduces the predictability of contribution schedules, creating costs for contributors (employers and employees). Other than adjusting contributions and benefits, a pension plan may reduce the variability in its funding ratio by seeking to invest its assets in a way that closely mirrors movements in its liabilities.

Funding ratios may be stated in nominal and in real terms. Nominal funding ratios exclude any indexation to accrued benefits or benefits in payment. Accrued benefits are calculated on the basis of current salaries while one assumes that pensions in payment will be constant over time. Real funding ratios, on the other hand, should in principle take full account of any indexation promised or targeted. As indexation is voluntary in most OECD countries, regulators normally use nominal funding ratios as their policy variable (see Pugh and Yermo (2008)). Some countries also require pension funds to hold a solvency margin above full funding. This is the case for example in Denmark, Finland, and the Netherlands. For the pension fund itself, sponsoring employers, and employees, the real funding ratio is a more relevant funding target, as the goal is to deliver benefits that at least keep up with the cost of living (price inflation) and if possible also with the standard of living (wage inflation).

The second key performance variable of a pension plan that we analyse is the replacement rate, defined as the ratio of a pensioner's benefit at retirement relative to his or her final wage before retirement. For a person to maintain his or her standard of living after retirement a reasonable target replacement rate is $70 \%$. This level considers the fact that pensioners typically do not need to contribute to pension systems, their lower consumption needs and in particular the fact that in most OECD countries a worker reaching retirement is (or was at some point) a home owner and hence spends only a small part of its disposable income on housing. Variability in the replacement rate reduces a worker's welfare by making it less likely that he or she will attain the target income at retirement.

The different pension plans described earlier can be evaluated on these two criteria by using a simple projection scenario that uses common assumptions:

- Same contribution rate (14\% of salary) and other basic plan rules (e.g. payment in the form of annuities)

- Same actuarial and economic assumptions (see appendix)

- Same investment policy (60-40 and 30-70 equity-bond allocation)

- Same regulations (e.g. minimum and maximum funding rules)

\footnotetext{
${ }^{20}$ Heller (2003). This situation is likely to worsen in response to population ageing. A greater number of retirees will be able to use their voting power to put extra pressure on the next (smaller) generation.
} 
The specific pension plans modelled are the following:

- Career-average defined benefit plan with unconditional indexation: this plan pays benefits that are a percentage of the career average wage, where both past wages and benefits in payment are indexed to the average rate of salary growth of plan members. Effectively, the replacement rate is fully guaranteed in real terms.

- Career-average defined benefit plan with conditional indexation: as above but indexation for purposes of calculating accrued benefits and for indexing pensions in payment depends on the plan's funding status. The conditionality affects all members, whether active, deferred or passive, in an equal way. The formula, or indexation ladder, used to calculate the extent of indexation is the one currently in place at Pensioenfonds Zorg \& Welzijn (PFZW), the second largest pension fund in the Netherlands. The indexation ladder is described in Box 1.

- Cash balance plan: this plan is based on a fixed indexation rate of $3.2 \%$ in nominal terms that is applied to accrued, deferred and currently paid benefits. This rate is equal to the expected wage inflation.

- Collective DC plan: benefits are calculated as under a career-average plan, but nominal benefits are cut when the nominal funding ratio is below 95\%, benefit cuts are made up when the nominal funding ratio goes above $105 \%$ and extra benefits are paid when it goes above $180 \%$.

- "Individual" DC plan: benefit are calculated on the basis of an individual account and market rates of return, but the contribution rate progressively increases over time in order to reflect the actuarial weighting of contributions in a defined benefit setting. The rising contribution rate schedule makes it possible to compare this plan with the other pension plans.

\section{Box 1: Explanation of the indexation ladder of PFZW}

The indexation ladder depends on both the nominal and real funding ratio of the fund. Any indexation given is linked to the wage inflation in the sector health care and social welfare. When the nominal funding ratio is below $105 \%$, no indexation is given. When it is above $130 \%$, full indexation is given, so the indexation is equal to the wage inflation. When the funding ratio is between $105 \%$ and $130 \%$, only a part of the indexation is given. If the funding ratio is for instance $117.5 \%$ (exactly in the middle of 105 and 130), half of the wage inflation is given.

When the real funding ratio is above $100 \%$, extra indexation is given. This extra indexation will only be given if any indexation in the past is missed and will be exactly as much as the indexation that is missed. For example, if in one year, the nominal funding ratio is $104 \%$ and the wage inflation is $3 \%$, then no indexation is given (the funding ratio is below $105 \%$ ). If a year later, the real funding ratio is above $100 \%$, full indexation of that year is given and on top of that, extra indexation of $3 \%$ is given, because that is the missed indexation of last year. Figure 1 shows the indexation ladder. 
Figure 1: Indexation ladder of PFZW

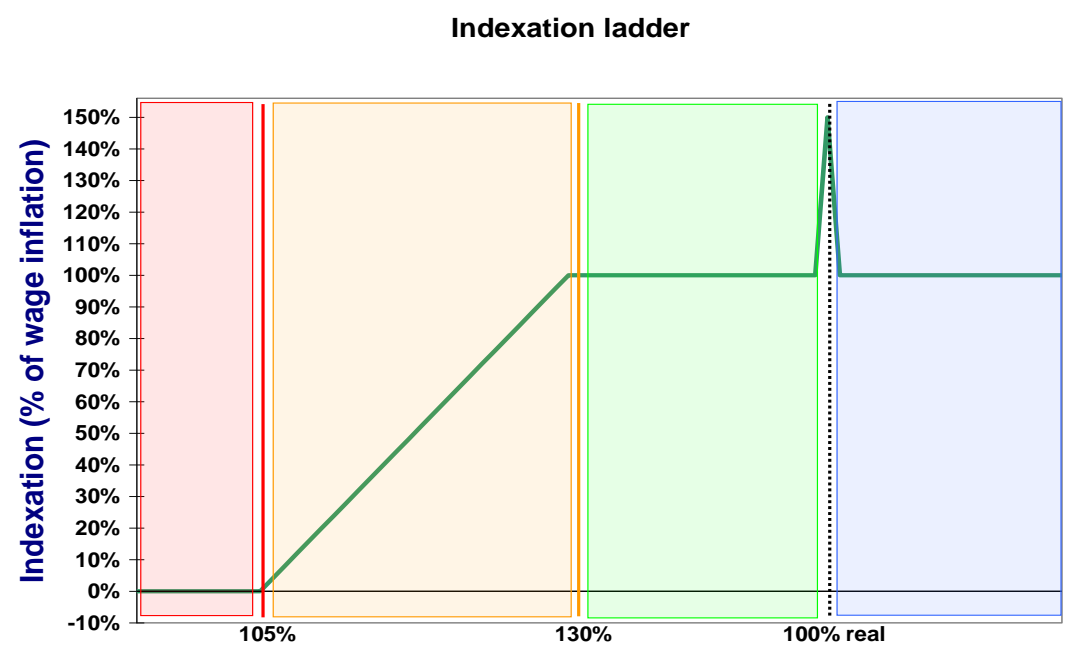

The funding ratio and benefit projections are based on Monte Carlo simulations. The funding ratio is calculated in both nominal and real terms. The real funding ratio is calculated using a real interest rate to discount future pension benefits ${ }^{21}$ and therefore overestimates the actual funding ratio if the pension fund wishes to pay wage indexation (instead of price inflation). The reason for using this approximation is that wage-adjusted discount rates are not available in the market. However, as wage inflation is assumed to be on average $1 \%$ above price inflation, the wage-based real funding ratio may be as much as $20 \%$ lower than the levels calculated using the price-based real discount rate.

The starting real funding ratio is set at $100 \%$. The simulation calculates 500 scenarios and generates the output in the form of dispersion of funding ratios and replacement rates over a projection period of 40 years $^{22}$. The 500 scenarios are real world scenarios. This means that they are forward looking and cannot be used to calculate market values.

The input of the model consists of 500 different scenarios of economic variables for 60 years into the future. The properties of these economic variables - like standard deviation and correlations - are based on past data, where the returns are based on PGGM assumptions. Table 1 shows some properties of the most important variables.

\footnotetext{
${ }^{21}$ The methodology for calculating the real funding ratio is discussed in Annex 2 (this annex is removed, so this should also be removed).

${ }^{22}$ From 25 to 65 , the assumed retirement age. We use 60 years scenarios to include 20 years of retirement.
} 
Table 1. Statistical properties of main financial and economic variables used in model

\begin{tabular}{|l|c|c|c|}
\hline & Average (arithmetic) & Average (geometric) & Standard deviation \\
\hline Wage inflation & $3.3 \%$ & $3.2 \%$ & $3.2 \%$ \\
\hline Price inflation & $2.0 \%$ & $2.0 \%$ & $1.9 \%$ \\
\hline Equity & $8.7 \%$ & $7.8 \%$ & $14.8 \%$ \\
\hline Bonds & $4.4 \%$ & $4.4 \%$ & $4.0 \%$ \\
\hline $\begin{array}{l}\text { Short interest rate } \\
\text { (3-month nominal) }\end{array}$ & $3.8 \%$ & $3.8 \%$ & $1.5 \%$ \\
\hline $\begin{array}{l}\text { Long interest rate } \\
\text { (30 years nominal) }\end{array}$ & $5.2 \%$ & $5.2 \%$ & $1.2 \%$ \\
\hline $\begin{array}{l}\text { Short interest rate } \\
\text { (3-month real) } \\
\text { Long interest rate } \\
\text { (30 years real) }\end{array}$ & $1.8 \%$ & $1.8 \%$ & $1.1 \%$ \\
\hline
\end{tabular}

Different kinds of investment policy were used in the models: a riskier portfolio of $60 \%$ equity and $40 \%$ bonds; and a safer portfolio of $30 \%$ equities and $70 \%$ bonds. Separate projections were also made for long maturity nominal bonds and index-linked bonds. ${ }^{23}$

Figure $1(\mathrm{a}$ and $\mathrm{b}$ ) shows the evolution of the nominal and real funding ratio for the traditional DB plan (unconditional indexation) with a 60-40 equity-bond asset allocation using nominal bonds. The level of the funding ratio is shown for the median path as well as 1\%, 5\%, 10\%, 90\%, 95\% and 99\% percentiles. The increasing range of possible levels of the funding ratio over time occurs because the contribution ratio (and indexation) is fixed, so volatility in the underlying variables has a cumulative impact on the funding ratio. The difference between the best and worst possible scenarios at the end of the projection period are abysmal (over 500\% in the best case scenario and close to $0 \%$ in the worst case).

Figure 1. Nominal and real funding ratio of the traditional DB plan (with 60-40 asset mix)
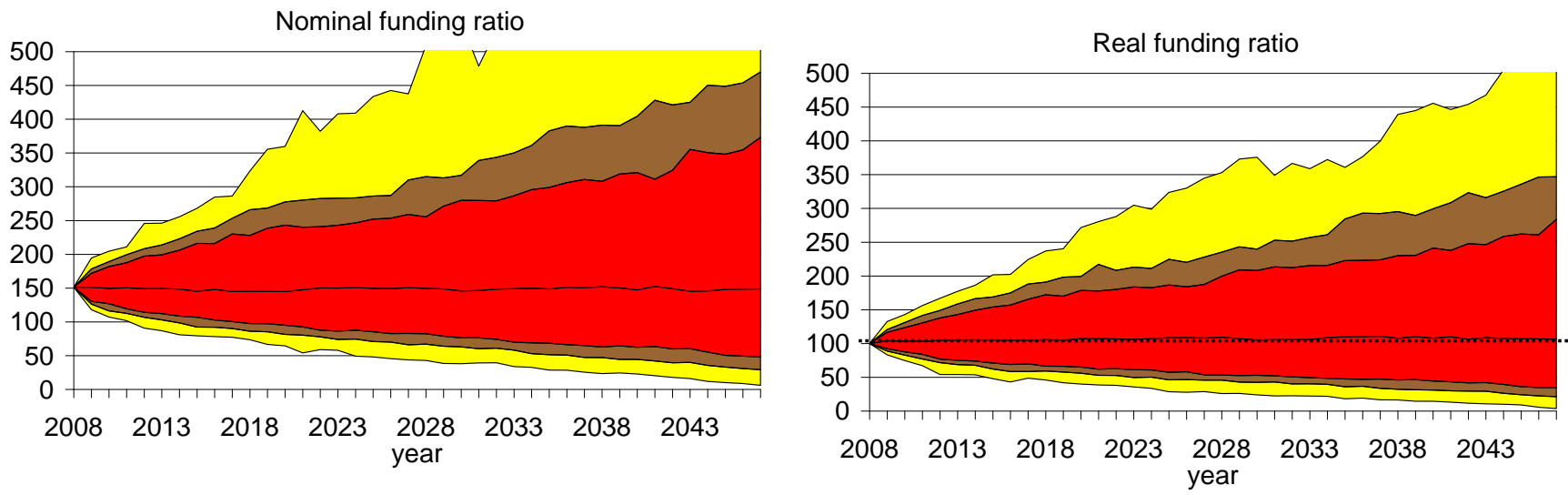

Figures 2 ( $\mathrm{a}$ and $\mathrm{b}$ ) and 3 ( $\mathrm{a}$ and $\mathrm{b}$ ) below show the outcomes of funding ratios and replacement rates at the end of the projection period (40 years) for the same asset allocation. The level of the variables is shown under a confidence interval of $+/-5 \%$, meaning that there is a $90 \%$ probability that the level of the variable will be within the bar shown in the figure after 40 years. The middle point indicated with a cross is the median level of the variable at the end of the projection period.

\footnotetext{
${ }^{23}$ These simulations are available upon request from the authors. They show higher funding ratios and replacement rates at all risk levels.
} 
Figure $2 \mathrm{a}$ shows the nominal funding ratios while Figure $2 \mathrm{~b}$ shows the real funding ratio. The real funding ratio shows a similar pattern across pension plans to that of the nominal ones but the ranges are much narrower. Figure $3 \mathrm{a}$ shows the range of replacement rates that may be reached with different degrees of certainty under the various pension plans. Finally, Figure $3 \mathrm{~b}$ shows the age at which a plan member may expect to reach a $70 \%$ replacement rate with different degrees of certainty. This chart quantifies the value of lower (higher) replacement rates relative to the $70 \%$ target in additional (fewer) years of work, that is in later (earlier) retirement.

Figure 2a. Nominal funding ratio projections for different pension plans at $t=40$.

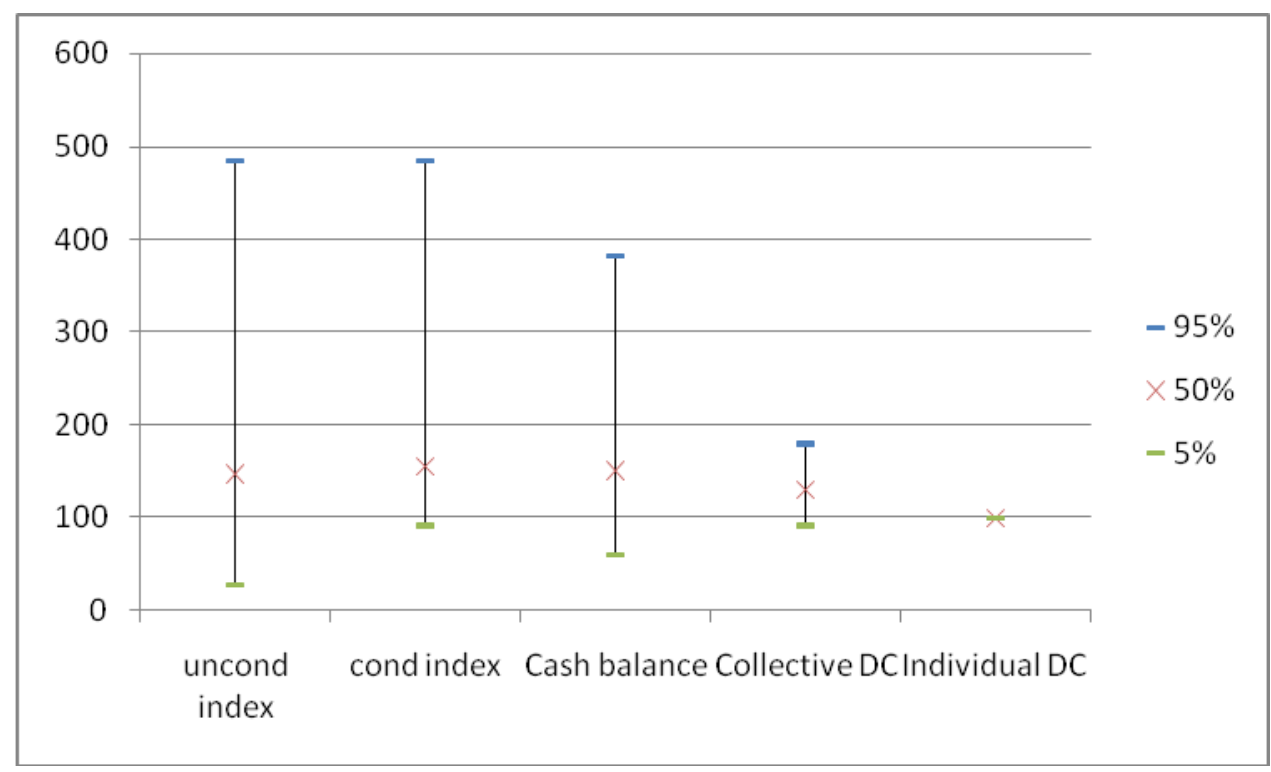

Figure $2 \mathrm{~b}$. Real funding ratio projections for different pension plans at $\mathrm{t}=\mathbf{4 0}$.

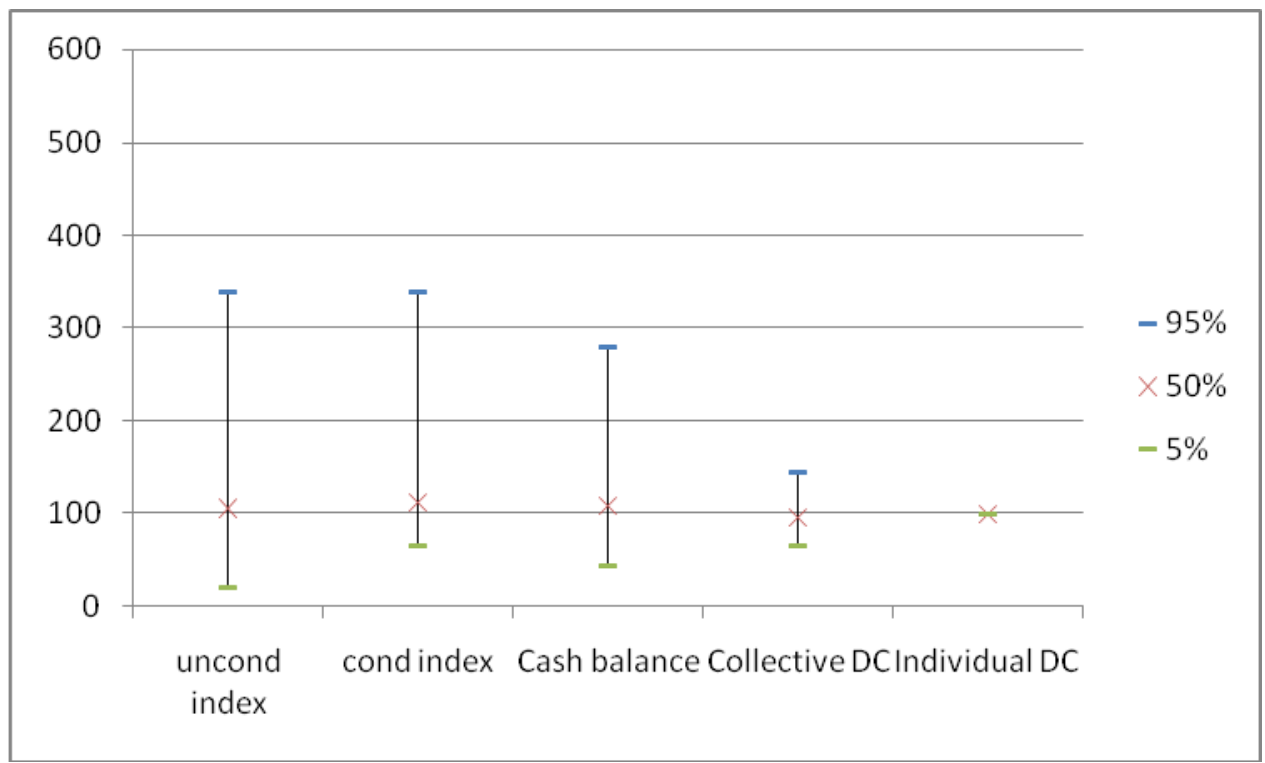


Figure 3a. Replacement rate projections for different pension plans at $t=40$.

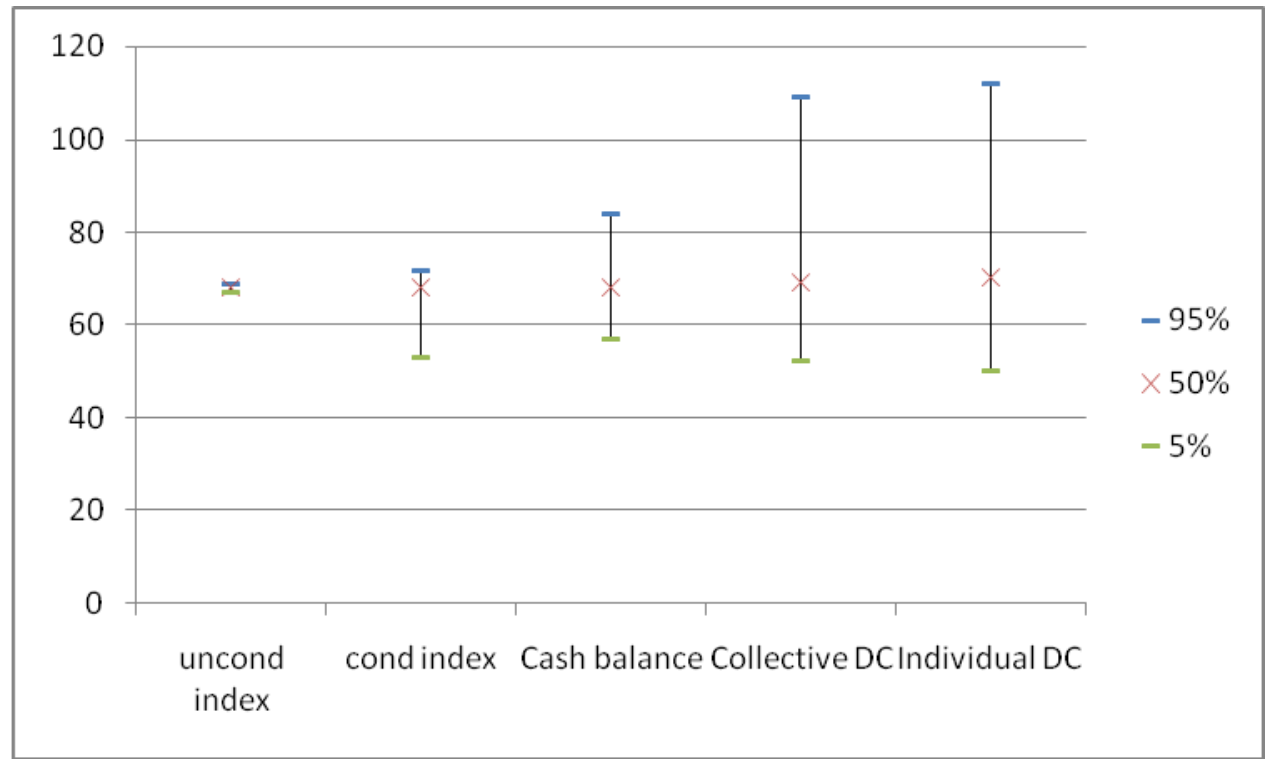

Figure 3b. Age required to reach $70 \%$ replacement rate for different pension plans.

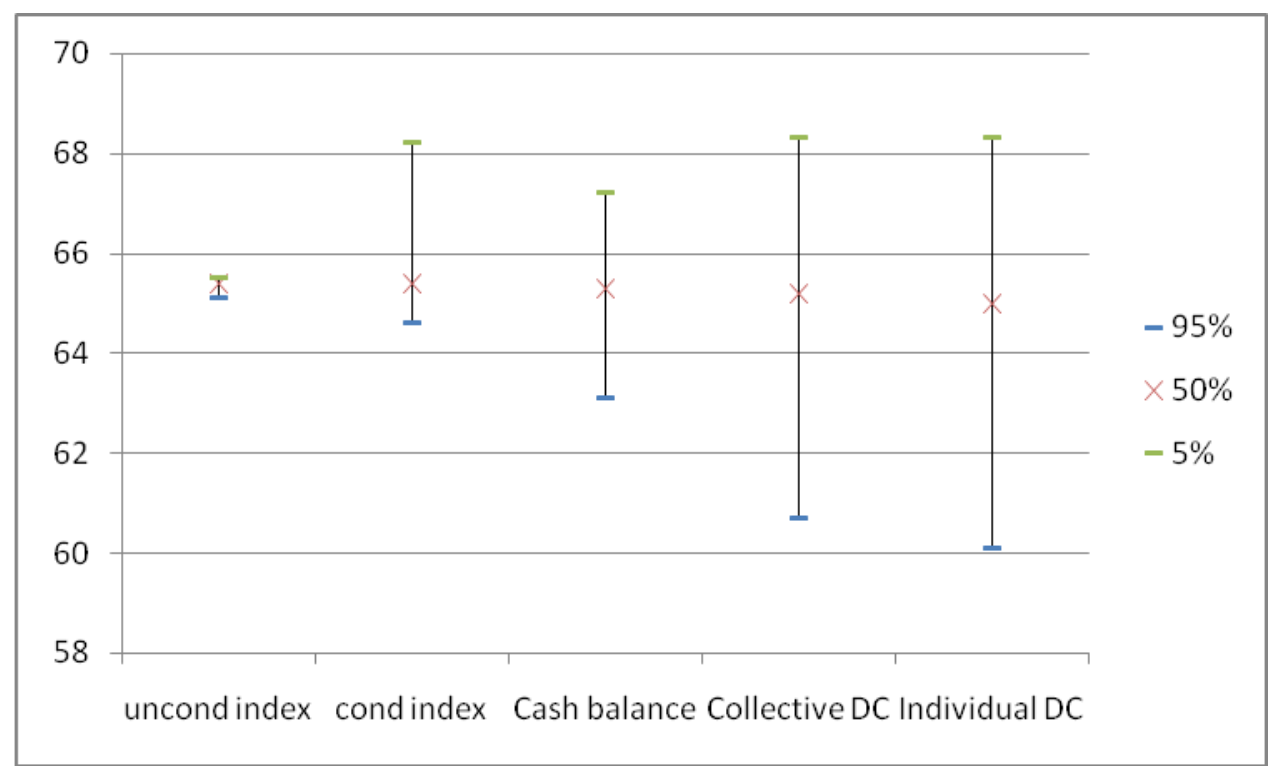

As can be observed contrasting Figures $2 \mathrm{a}$ and $2 \mathrm{~b}$ against $3 \mathrm{a}$ and $3 \mathrm{~b}$, risk manifests itself in either the funding ratio or in the replacement rate. As the projections assume a fixed contribution rate, the greater the security sought in the replacement rate (the smaller the range of possible outcomes) the greater the variability in the funding ratio. The range of possible funding ratio outcomes and replacement rates is very large. At one extreme, the plan with unconditional indexation (the first on the left of both figures) offers a replacement rate of around $70 \%$ under all scenarios, but the corresponding funding ratio can range between 20 percent and nearly $340 \%$ (funding ratios below and above these levels have each a $5 \%$ probability). At the other extreme, a pure DC plan is fully funded at all times, but leads to a range of possible replacement rates from $50 \%$ to $112 \%$. As shown in Figure 2b, the worst $5 \%$ of scenarios for the pure DC plan (a replacement rate lower than 50\%) can also be interpreted as requiring for at least an additional three years of work in order to achieve the target $70 \%$ replacement rate. 
The pension plans in between are various forms of risk sharing arrangements that involve variability in both funding ratios and replacement rates, but at narrower ranges than in the two extreme cases. In particular, the conditional indexation plan reduces some of the risk of underfunding but introduces a risk of lower (and to some extent also higher) replacement rates than under the unconditional scenario case.

The cash balance plan offers improved upside potential on replacement rates, while lowering the risk of overfunding and raising the risk of underfunding relative to the conditional indexation plan. The collective DC system in turn provides greater security over the funding ratio but at the expense of a larger variability of the replacement rate. In fact, this last plan provides benefit outcomes that are not that different to those of a pure DC plan.

\section{How to select 'optimal' pension plans}

How should employers and employees choose among the different pension plans described above? From the perspective of a risk-averse worker, the career-average plan with unconditional indexation would seem to be the natural choice. The replacement rate offered by this plan (around 70\%) is nearly equal to that of the average scenario under any of the other pension plans. But all the other plans expose the worker to the possibility that benefits will be lower or higher than this average level.

However, a promise of a fixed replacement rate requires someone to manage the risks of the funding ratio. As regulators set constraints to both under- and overfunding to limit, respectively, solvency risks and tax abuse, highly variable funding ratios need to be corrected via changes in the contribution policy. This means in turn that workers are ultimately exposed to changes in their net wages. Security in pensioners' income ultimately translates into insecurity in workers' income. ${ }^{24}$

By accepting a somewhat more volatile replacement rate after retirement employers and employees can be exposed to a less volatile funding ratio. Employers, workers, and pensioners need to decide on a suitable trade-off between funding and benefit volatility that meets their respective concerns. Volatile funding ratios imply volatile consumption for active members (the pension fund will use the contribution policy to steer the funding ratio to sustainable levels); volatile replacement rates imply volatile consumption changes around the retirement age. Since individuals seek to smooth their consumption patterns throughout their life, hybrid systems using both contribution rates and benefits (replacement rates) as policy instruments would appear to dominate systems using only one of the two instruments.

However, all of these risk sharing pension plans require a commitment on the part of the different stakeholders to honour their commitments. Are such commitments sustainable over time? A generation that under a risk-sharing plan is exposed to higher contribution rates could also end up at retirement with lower replacement rates than the previous generation. Hence, it may be argued that the higher the dispersion in benefit outcomes the less likely that workers will be willing to support current beneficiaries via increases in contributions.

While it is difficult to generalise on this issue, it would seem that the cash balance plan is at greatest risk of suffering such generational conflicts. Both the conditional indexation plans and the collective DC plan lower the risk of underfunding to such a degree that makes it very unlikely that there will be a need to vary contribution rates. Only in the worst $5 \%$ of scenarios is the real funding ratio below $65 \%$, while the nominal funding ratio only falls below $94 \%$ (in the conditional indexation plan) and $91 \%$ (in the collective DC plan) under the worst $5 \%$ of scenarios. On the other hand, under a cash balance plan, the real and nominal funding ratios are expected to be below $46 \%$ and $63 \%$, respectively, in the worst $5 \%$ of

\footnotetext{
${ }^{24}$ The ageing society makes this insecurity even larger. The risk of a growing, larger number of pensioners is borne by a small, declining number of workers.
} 
scenarios. As pension regulators focus mainly on nominal funding ratios, at least when indexation is not guaranteed, the contribution policy of the cash balance plan is likely to be very volatile.

The conditional indexation suffers from a different type of problem, which is the possibility of building large funding surpluses or excess funding. ${ }^{25}$ Such outcomes may not only lead to demands for higher benefits but are in practice prohibited by tax authorities in many countries who fear that pension funds are used for tax abuse. ${ }^{26}$ A practical solution to situations of very high levels of overfunding is to engage in contribution holidays, as is the case in traditional defined benefit plans. However, there may be demands for higher benefits from current pensioners. Conditional indexation plans therefore call for a transparent and intergenerationally satisfactory policy on how very large funding surpluses will be allocated.

Generational tensions over funding deficits and surpluses in general favour pension plans such as those exemplified by the collective DC plan modelled in the previous section. Underfunding leads to lower benefits while overfunding leads to higher benefits, following a clear policy rule. However, both workers and pensioners may question the value of risk sharing under this plan as the downside and upside risks are very similar to those of a pure DC plan. The extent of risk sharing in collective DC plans is dependent on the levels at which the pension funds cuts and increases benefits ${ }^{27}$.

These arguments are summarised in Table 2 in a very synthetic form in order to assess the sustainability of these different pension plans along three different dimensions of risk sharing: the predictability of the replacement rate, the risk of higher contribution rates, and the risk of high funding ratios (build-up of large surpluses). The scores are based on a $+/$ - formulation, where "+" indicates a positive outcome from the perspective of members and "-"indicates a negative outcome. The numbers of pluses of minuses indicates the importance of the effect. The pure DC plan is given a zero score on all three indicators so it is used as the reference against which all other plans are scored.

The more predictable and stable the benefits, the greater the value of the pension arrangement for plan members. On the other hand, a greater risk of higher contribution rates lowers the value of the arrangement. Finally, the build-up of large surpluses can also lead to demands for special pay-outs or lower contributions and hence jeopardise the viability of the pension arrangement in question. However, as mentioned before, large surpluses can be allocated via an intergenerationally satisfactory rule. They are in general less threatening to the perceived value of pension arrangements than increases in contribution rates.

\footnotetext{
${ }^{25}$ Another problem is when inflation is low, steering with indexation is not very powerful.

${ }^{26}$ However, some buffers may be needed for risk borne by the pension fund, as required by regulators in some European countries.

${ }^{27}$ In the collective DC plan, we assumed cutting benefits below a nominal funding ratio of $95 \%$ and increasing them above $180 \%$ (see paragraph 29.). A wider interval (without cutting and increasing benefits), will lead to more secure benefits and a wider dispersion of the funding ratio. We have not tried to optimise the various pension systems.
} 
Table 2. Aspects of risk sharing of different pension plans.

\begin{tabular}{|l|l|l|l|}
\hline Pension plan & $\begin{array}{l}\text { Level and predictability } \\
\text { of replacement rate }\end{array}$ & $\begin{array}{l}\text { Risk of higher contribution } \\
\text { rates }\end{array}$ & $\begin{array}{l}\text { Risk of high funding } \\
\text { ratios }\end{array}$ \\
\hline $\begin{array}{l}\text { DB, unconditional } \\
\text { indexation }\end{array}$ & ++++ & ---- \\
\hline $\begin{array}{l}\text { DB, conditional } \\
\text { indexation }\end{array}$ & ++ & - & ---- \\
\hline Cash balance & +++ & --- & --- \\
\hline Collective DC & + & - & - \\
\hline Pure DC & 0 & 0 & 0 \\
\hline
\end{tabular}

\section{Concluding remarks}

This study has evaluated the attractiveness of different types of pension arrangements from the perspective of the members by analysing the trade-off between the uncertainty in contributions on the one hand, and benefits on the other that is embedded in different pension arrangements. The paper employed the funding ratio (ratio of assets to liabilities) and the replacement rate (ratio of benefits to salaries) as key criteria for evaluating the risk sharing characteristics of the various private pension plans or schemes from the perspective of the plan member. This trade-off is dependent on the risk sharing characteristics within the various schemes, irrespective of whether it is the employer, employees, or a combination of both that pays contributions. The pension arrangements considered range from the traditional DB plan where the replacement rate is guaranteed in real terms (no benefit risk) to the pure or individual DC plan where individual members bear fully the uncertainty of the level of benefits stemming from three main sources of risk (investment, inflation and longevity).

Our simulations (focusing on inflation and investment risks) show that hybrid plans (those in between traditional DB and individual DC) may entail more efficient and sustainable forms of risk sharing. Conditional indexation plans offer high levels of predictability of replacement rates, have a low risk of requiring higher contribution rates to correct underfunding and only suffer from a high risk of building up large funding excesses. But it was also shown that the latter feature is ultimately more a blessing than a curse. In contrast, collective DC plans do not suffer from the risk of high funding excesses, but they expose pensioners to substantial replacement rate risk, offering a range of benefit outcomes that is not that different from individual DC plans. The cash balance plan modelled offers lower downside risk to replacement rates than either of the previous two deals but suffers from a substantial risk of underfunding, and hence higher contribution rates. However, it should be noted that this underfunding risk is driven by the assumption of a fixed rate of return assumption on contributions. In practice, cash balance plans may index returns (and benefits) to a market rate of return, such as a government bond rate, which would make underfunding less problematic but would lead to greater risk in benefit levels.

In sum, in today's regulatory, social and economic environment, conditional indexation plans seem to have the greatest potential to deliver high, predictable pensions, while maintaining some stability in contribution costs, thereby suggesting themselves as a sustainable form of risk sharing. An improved version of a conditional indexation plan than the one considered here may involve greater security for pensioners over indexation in exchange of greater upside over benefits (access to the funding excess) for active members. Ultimately, however, the choice of a specific pension arrangement depends on the preferences of employees and pensioners, and in particular their degree of risk aversion and their ability or willingness to commit to an intergenerational risk sharing contract. 
In a follow-up study we intend to extend our study by addressing also longevity risk in the simulations and by calculating the distribution of the net economic value of the various pension arrangements across employees of different ages and pensioners. 


\section{REFERENCES}

Aarssen, K. and Kuipers, B.J. (2007), "Everyone gains, but some more than others”, in O.W. Steenbeek and S.G. van der Lecq (ed), Costs and Benefits of Collective Pension Schemes, Springer.

Antolin, P. and H. Blommestein (2007), "Governments and the market for longevity indexed bonds" OECD Working Paper on Insurance and Private Pensions 4.

Ball, L. and N. G. Mankiw, (2007), Intergenerational Risk Sharing in the Spirit of Arrow, Debreu, and Rawls, with Applications to Social Security Design, Journal of Political Economy, Vol. 115 no. 4.

Boeijen, T.A.H., Jansen, C., Kortleve, C.E. and J.H. Tamerus (2007), "Intergenerational solidarity in the uniform contribution and accrual system", in O.W. Steenbeek and S.G. van der Lecq (ed), Costs and Benefits of Collective Pension Schemes, Springer.

Blommestein, Hans (2006), "What are the factors for a successful market in longevity-indexed government bonds (LIBs)? A public debt management perspective" Pensions Management - An International Journal, volume 11, Issue 2, Palgrave McMillan.

Bohn, Henning (2005), "Who Bears What Risk? An Intergenerational Perspective, Pension Research Council Working Paper PRC WP 2005-7.

Brown, J.R. and Peter R. Orszag (2006), "The Political Economy of Government Issued Longevity Bonds", Paper presented at the Second International Longevity Risk and Capital Market Solutions Conference, April.

Byrne, Alistair and Debbie Harrison (2005), “Is longevity risk a one-way market?” Report of the First International Conference on Longevity Risk and Capital Market Solutions, held on 18 February 2005, London.

Continuous Mortality Investigation, CMI, (2005a), "Projecting future mortality: Towards a proposal for a stochastic methodology", Mortality Committee, Working Paper 15.

Continuous Mortality Investigation, CMI, (2006), "Stochastic projection methodologies: Further progress and P-spline model features, example results and implications", Mortality Committee, Working Paper 20.

European Commission (2006), "The Impact of Ageing on Public Expenditure: Projections for the EU25 Member States on pension, health care, long-term care, education and unemployment transfers (2004-2050)" European Economy Special Report 1/2006.

Fernandes, F. (2005), "Longevity Bond: A pension fund perspective", Presentation at the First International Conference on Longevity Risk and Capital Market Solutions, held on 18 February 2005, London. 
Heller, Peter (2003), "Who Will Pay? Coping with Aging Societies, Climate Change and Other LongTerm Fiscal Challenges" IMF, Washington D.C.

McCarthy, D. (2003), "A Life-Cycle Analysis of Defined Benefit Pension Plans", Journal of Pension Economics and Finance, Volume 2, Issue 2, July 2003.

Morgan Stanley, Challenges to Market Development, Presentation at the First International Conference on Longevity Risk and Capital Market Solutions, 18 February 2005, London

OECD (2009), Private Pensions Outlook, OECD: Paris.

Pugh, C. and Yermo, J. (2008), "Funding Regulations and Risk Sharing", OECD Working Paper on Insurance and Private Pensions No. 17, April 2008.

Richards, Stephen and Gavin Jones (2004), "Financial aspects of longevity risk", Paper presented to the Staple Inn Actuarial Society, London, 26 October 2005.

Roberts, Philip (2005), “A practical framework for facilitating longevity risk transfer", Presentation at the First International Conference on Longevity Risk and Capital Market Solutions, 18 February 2005, London.

Schroeder, Thomas and David Clark, What are the key factors that will drive the longevity bond market?, paper presented at the "Seventh Annual OECD-World Bank Global Bond Market Forum", held on 23-24 May 2005 in Washington D.C 


\section{ANNEX 1: CHANNELS OF RISK TRANSFER}

This annex discusses several proposals for risk transfer. As in the main text, we will take longevity risk as a concrete example. This risk transfer is needed or should be considered when pension funds (or annuity providers) are not capable to absorb and manage efficiently longevity risk ${ }^{28}$. Transferring the longevity risk of pension fund $\mathrm{s}^{29}$ and annuity providers can then in principle take place via four principal channels: ${ }^{30}$

- Protection seeker takes insurance from re-insurers.

- Conversion of DB benefits to annuities via bulk 'buy outs'.

- Annuity provider writes balancing insurance product. ${ }^{31}$

- Capital market solutions.

Re-insurance companies have a fairly limited underwriting capacity. As a rule, re-insurers do not take on longevity risk, unless it is for an existing client and part of an overall package of risks, while capped at a relatively small level. ${ }^{32}$ As a result, the appetite of re-insurers for longevity risk transaction seems to be rather small at this stage, although this situation can improve with more precise knowledge of this risk and growing risk transfer demand.

Also the capacity of the buy-out market is rather small. The conversion of DB benefits to annuities is both very expensive, while insurance capacity is very limited. Initially, the UK buy-out market shrunk,

\footnotetext{
${ }^{28}$ It can be argued that an important intermediary function of pension funds is to absorb and manage longevity risk. This means that, in principle, active member take over the risk from the pensioners. Pension funds would then make markets more complete by delivering this risk-management service to pensioners. Naturally, this risk should be properly priced and pension funds (in particular the larger ones) should have the required expertise and comparative advantage in managing longevity risk. In this way, active members (and other stakeholders taking over these risks) are (and indeed can be) properly rewarded.

${ }^{29}$ Longevity risk faced by pension funds can also be managed via a forward-looking contribution policy (e.g. by including improved longevity in the calculation of future liabilities and by including margins). A forwardlooking contribution policy acts to some extent also as a hedge.

${ }^{30}$ Thomas Schroeder and David Clark, What are the key factors that will drive the longevity bond market?, paper presented at the "Seventh Annual OECD-World Bank Global Bond Market Forum", held on 23-24 May 2005 in Washington D.C; Stephen Richards and Gavin Jones (2004), Financial aspects of longevity risk, Paper presented to the Staple Inn Actuarial Society, London, 26 October 2005; Morgan Stanley, Challenges to Market Development, Presentation at the First International Conference on Longevity Risk and Capital Market Solutions, 18 February 2005, London.

${ }^{31}$ Some pension funds have bought (general) protection for downside risks (e.g. put options to protect against deficits).

${ }^{32}$ Stephen Richards and Gavin Jones (2004), ibid.
} 
with only two major re-insurers active. ${ }^{33}$ However, more recently (during the last 1-2 years), there has been a significant increase in the UK buy-out market.

The third way of transferring longevity risk is based on hedging through balancing products. An obvious example is the case where a holder of longevity risk would enter into a contract with a term assurance portfolio, thereby combining a conventional level annuity with a whole-life assurance to the value of the cost of the annuity. The resulting combination of the underlying risks (mortality and longevity risk) would then reduce an insurer's exposure to future increases in longevity, thereby also reducing the capital reserves held in respect of this risk.

The very limited capacity of the first three channels for transferring longevity risk has prompted the search for capital market solutions. This last channel for transferring longevity risk would allow protection seekers to buy longevity bonds. ${ }^{34}$ This capital market channel will be discussed in the remainder of this section.

Proposed solutions for reducing the exposure to longevity risk of pension funds and annuity providers are conceptually simple, as they require the construction of capital market instruments linked to a reliable longevity index. Given a suitable index it would be possible to construct longevity bonds with either the coupon or principal (or both) at risk of default if longevity improvements in excess of expectations occurred. ${ }^{35}$ These instruments can then be used to hedge mortality and longevity risk. ${ }^{36}$ However, most longevity products that are currently being developed or offered offer a hedge against current longevity risk. Pension funds are also interested in hedging future longevity risk (the likelihood that someone who is of 25 years old to-day will live 5 years longer is substantially higher than for someone who is already 80 ).

Although life insurers and pension funds have similar liabilities, they have different perspectives. ${ }^{37}$ Insurance companies are concerned about potential catastrophic losses, while pension plans aim to protect corporate cash flows from incremental losses.

However, in practice it is unlikely that the private-sector will be successful in the short-term. Research has identified a number of key obstacles that explain why a large scale private-sector driven

33 Alistair Byrne and Debbie Harrison, Is longevity risk a one-way market?, Report of the First International Conference on Longevity Risk and Capital Market Solutions, held on 18 February 2005, London.

${ }^{34}$ Other financial market products can in principle also provide a (partial) hedge. For example, with people living longer, they will also consume longer. As a result, many companies will make more profits, in particular the medical sector and other ageing-related companies. This in turn would imply that that also equity markets would provide (to some degree at least) a hedge against longevity risk.

${ }^{35}$ Stephen Richards and Gavin Jones (2004), ibid.

${ }^{36}$ This is likely to be a partial hedge as in practice significant basis risk - a portfolio of annuitants or members of pension plans or insurance schemes may exhibit a very different pattern of longevity improvements compared to the underlying index for a bond - will remain in portfolios or pension and insurance schemes. For example, Francis Fernandes (2005) argues that basis risk could be of the order of $20 \%$. More in general, an index linked to the general population will imply a basis risk for the pension plan, since the longevity of members of a pension fund is generally higher. [Note that working part of the population has a higher life expectancy than the total population (because the latter also includes 'sick' people)].

${ }^{37}$ Philip Roberts (2005), A practical framework for facilitating longevity risk transfer, Presentation at the First International Conference on Longevity Risk and Capital Market Solutions, 18 February 2005, London. 
market in longevity products is unlikely to develop in the near future. ${ }^{38}$ For this reason many analyst have proposed a central capital market role for public policy by issuing longevity-indexed bonds. However, this public policy role is hampered by the fact (as noted above) that - on a balance sheet basis governments themselves are already exposed to significant longevity risk. This means that issuing longevity-indexed government bonds (LIBs) would further increase their current exposure. Earlier one of us had concluded that the prospects for a successful, large scale market in LIBs seem not favourable at this stage. ${ }^{39}$ It is also doubtful whether relatively small government issues of LIBs would suffice to create a benchmark around which large-scale capital-market solutions by the private sector could develop.

But perhaps the government can play an important role in overcoming a number of important difficulties related to market practices and conventions such as indices and types of indexation. ${ }^{40}$ Indices need to be developed so they can be embedded in LIBs. Since these indices provide the benchmark against which future mortality will be measured, they need to be simple and transparent, based on robust data, statistically credible, and calculated in an unbiased manner. ${ }^{41}$ Statistics produced by government agencies can meet these criteria as long as they can act as independent professional institutions (i.e. they need to be free from day-to-day political pressures). Another practical problem is related to market scepticism around the stochastic mortality models to predict future mortality. Overcoming these obstacles will support finding capital market solutions (e.g. new products) by private agents.

\footnotetext{
${ }^{38}$ Hans J. Blommestein (2006), "What are the factors for a successful market in longevity-indexed government bonds (LIBs)? (a public debt management perspective)" Pensions Management - An International Journal, Volume 11, Issue 2, Palgrave Macmillan.

${ }^{39}$ Blommestein (2006), ibid.

${ }^{40}$ Since the government is one of the stakeholders, it is desirable that an independent government agency is involved in setting market standards (as suggested below). Also professional, highly reputable organisations can be involved. For example, in the Netherlands, the Actuarial Society (Actuarieel Genootschap) produces mortality tables (including expected trends).

${ }^{41}$ Phil Roberts (2005), ibid.
} 